[Agr. Biol. Chem., Vol. 31, No. 10, p. 1195 1200, 1967]

\title{
Protein-Calcium-Phytic Acid Relationships in Soybean
}

\author{
Part I. Effects of Calcium and Phosphorus on Solubility \\ Characteristics of Soybean Meal Protein
}

\author{
By Kyoko Sato, Emiko Koyama* and Tokuji Watanabe \\ Food Research Institute, Ministry of Agriculture and Forestry, *Japan Tofu Association \\ Received June 9, 1967
}

\begin{abstract}
This paper constitutes the first report in a research series undertaken in order to clarify the interactive relationships among soybean meal protein, calcium and phytic acid in solution and in precipitate.

Data presented are mainly concerned with solubility characteristics of soybean meal proteins as a function of $\mathrm{pH}$. The results support the suggestion as follows; phosphorus and calcium give the remarkable effects on solubility characteristics of protein, the complex containing protein, calcium and phosphorus is formed above isoelectric point of protein and the combinations are labile above at $\mathrm{pH} 8$, especially by heating.
\end{abstract}

Soybean meals contain 500 600 mg of phosphorus on dry basis, 70 80\% of which account for phosphorus of phytic acid.

It has been reported that phytic acid influences the solubility characteristics of the meal protein by the combination with basic radicals in protein molecule below its isoelectric point. $^{1 \sim 31}$ In the course of the investigation, it was found that fairly large quantity of phosphorus precipitates with protein at about $\mathrm{pH} 5.7$ by calcium salt, and practically, $70 \sim 80 \%$ of water extractable phosphorus transfer into curd (tofu) in the process of coagulation." Wolf and Briggs reported that cold-insoluble fraction of soybean meal protein precipitated by cooling after addition of calcium chloride contained $1.40 \%$ of phosphorus, compared to a $0.17 \%$ of phos-

1) T. D. Fontaine, W. A. Pons, Jr, and G. W. Irving, Jr., J. Biol. Chem., 164, 487 (1946).

2) A. K. Smith and J. J. Rackis, J. Am. Chem. Soc., 79,633 (1957).

3) J.E. Courtois and P. Delrieu, Biochem. appl., 5, 65 (1958),

4) O. Nakayama, C. Fukamachi, S. Kubo, S. Suruga, S. Miyanaga, S. Horike and T. Watanabe, Report of the Food Research Institute, 14B, 52 (1960). phorus content in cold-insoluble fraction precipitated in the absence of calcium ion. ${ }^{6}$ ) These data indicate that protein easily combines with phytic acid in the presence of calcium even above its isoelectric point. But little attention has been paid to the relationship between protein and phytic acid above isoelectric point, since previous investigations dealt with almost exclusively with the relationship below isoelectric point.

This work was started in order to clarify interactive relationships among soybean meal protein, calcium and phytic acid in solution and also in precipitate by acid or calcium salt.

\section{MATERIAL AND METHODS}

Material. Hawkeye soybeans, 1965 crops, were used throughout this study. The defatted soybean meal was prepared by grinding, removing the hulls and defattening with a continuous flow of $n$-hexane.

Preparation of samples. Whole water extract; to $18 \sim 20 \mathrm{~g}$ of defatted soybean meal, $150 \mathrm{ml}$ of water was added and the mixture was stirred for $30 \mathrm{~min}$,

5) W. J. Wolf and D. R. Briggs, Arch. Biochem. Biophys., 186,85 (1959). 
centrifuged* and filtered through several layers of gauze.

Acid-precipitated protein; whole water extract was acidified to $\mathrm{pH} 4.25$ with $\mathrm{HCl}$ and the precipitate was centrifuged, washed twice with a small amount of water and dissolved in dilute alkaline solution until about $\mathrm{pH} 8$ with $\mathrm{NaOH}$.

Calcium precipitated protein; calcium chloride was added to whole water extract to make it $0.02 \mathrm{~N}$ with respect to added calcium ion and the precipitate was centrifuged, washed twice with a small amount of water and dissolved in dilute alkaline solution.

Cold-insoluble fraction; it was prepared after Wolf's method.6) To $40 \mathrm{~g}$ of defatted soybean meal, $200 \mathrm{ml}$ of water containing $0.01 \mathrm{M}$ mercaptoethanol was added, and the mixture was stirred for $30 \mathrm{~min}$, centrifuged and filtered through gauze. After standing in ice bath for $3 \sim 4 \mathrm{hr}$, the precipitate resulted was separated by centrifugation at $10,000 \times \mathrm{g}$ for $30 \mathrm{~min}$.

Phytate-free protein; it was prepared mainly after Graine's method. To the solution containing $5 \mathrm{~g}$ of fresh acid-precipitated protein, $25 \mathrm{~g}$ of Dowex-1-X10 resin (acetate form) was gradually added, the mixture being kept at $\mathrm{pH} 2.5$ and stirred for $15 \mathrm{~min}$. The solution was filtered through glass wool to remove the resin and treated a second time with $25 \mathrm{~g}$ of resin.

Experiments on solubility characteristics. For preliminary experiment, whole water extract was made different $\mathrm{pH}$ values or different calcium concentrations with $\mathrm{HCl}$ or calcium chloride, and precipitates resulted were centrifuged and analyzed for the amounts of nitrogen and phosphorus. Nitrogen was determined by micro-Kjeldahl method and phosphorus by Nakamura's method. ${ }^{\text {) }}$

Solubilities of nitrogen, calcium and phosphorus of whole water extract, solutions of acid-precipitated protein, calcium-precipitated protein, cold-insoluble fraction and phytate-free protein were determined at different $\mathrm{pH}$ values in the range of $\mathrm{pH} 2 \sim 11$. The protein solutions were respectively pipetted in $8 \mathrm{ml}$ and were adjusted to the various $\mathrm{pH}$ values by $\mathrm{HCl}$ or $\mathrm{NaOH}$. Each solution was filled up to $10 \mathrm{ml}$

* Centrifugation was carricd out at $1,000 \times \mathrm{g}$ for $15 \mathrm{~min}$, unless other wise stated.

6) D. R. Briggs and W. J. Wolf, Arch. Biochem. Biophys., 72, 127 (1957).

7) E. M. Graine and K. E. Fahrenholtz, Cereal Chem., 245, 35 (1958).

8) M. Nakamura, J.Agr. Chem. Soc. Japan, 3, $244(1950)$ with water and then centrifuged at $1,000 \times \mathrm{g}$ for 1 . min or in some case ultracentrifuged at $80,000 \times$, for $30 \mathrm{~min}$. Each supernatant was submitted to thi determination of total nitrogen, protein nitrogen phosphorus and calcium. Total nitrogen was deter mined by micro-Kjeldahl method and protein nitroger by micro-Kjeldahl method after precipitation wit? $10 \%$ of trichloroacetic acid. Phosphorus was deter. mined by Nakamura's method and calcium by Kubc and Tsutsumi's method ${ }^{9 /}$ after ashing aliquots of each supernatant and removing silicic acid. The values on $\mathrm{Y}$ axis in Figs. illustrating solubility characteristics indicate mg of nitrogen, calcium and phosphorus per $\mathrm{ml}$ of protein solutions. The values were recalculated as those in solutions containing $5 \mathrm{mg}$ nitrogen per $\mathrm{ml}$ because of the small variation of nitrogen content of sample solutions.

Five $\mathrm{ml}$ of sample was set on the column of Sephadex $\mathrm{G}-75,1.5 \mathrm{~cm} \times 30 \mathrm{~cm}$, eluted with $10^{-5} \mathrm{~N}$ $\mathrm{NaOH}$ and fractionated in $3 \mathrm{ml}$. Each tube was examined on the absorbance at $280 \mathrm{~m} \mu$, protein by Lowry's method, ${ }^{10)}$ phosphorus by Nakamura's method and calcium by Yanagisawa's method.11) For the gel-filtration of calcium-precipitated protein solution as well as calcium chloride solution shown in the top and middle in Fig. 4, their $\mathrm{pH}$ values were adjusted to 9.0. In the case of acid-precipitated protein solution shown in the bottom in Fig. 4, the pH was also adjusted to 9.0 after calcium chloride was added to make the final concentration $0.02 \mathrm{~N}$.

Heat treatment. To discuss the effects of heating on solubility, whole water extract was heated on boiling water bath for $10 \mathrm{~min}$ and was submitted to the determination of solubility characteristics. Because of the difficulty of homogeneous pipetting for precipitates resulted by heating, acid-precipitated protein, calcium-precipitated protein solutions and also whole water extract were first pipetted, adjusted the $\mathrm{pH}$ values and then heated on boiling water bath for $10 \mathrm{~min}$.

\section{RESULTS AND DISCUSSION}

The amounts of the nitrogen and phosphorus precipitated from whole water extract at dif-

9) S. Kubo and C. Tsutsumi, Report of the Food Research Institute, 5, 171 (1951).

10) O. H. Lowery, N. J. Rosebrough, A. L. Farr and R. J. Randall, J. Biol. Chem., 193, 265 (1951).

11) F. Yanagisawa, Analysis and Instrument, Japan, 4, 59 (1966). 

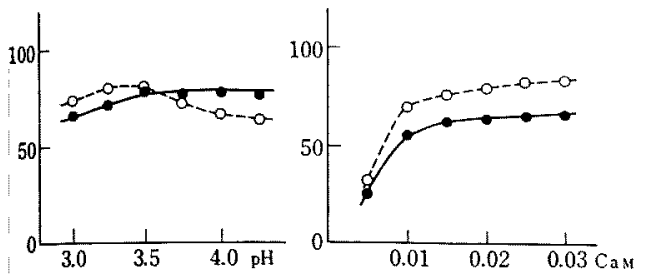

i. 1. Percentage of $\mathrm{N}$ ind P Precipitated from Whole Water Extract at Different $\mathrm{pH}$ Values

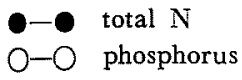

FIG. 2. Percentage of $\mathrm{N}$ and P Precipitated from Whole Water Extract at Different Calcium Concentrations.

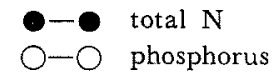

rent acidic $\mathrm{pH}$ values are shown in Fig. 1 the percentage to those of whole water tract. The maximum precipitation in total losphorus occurs at about $\mathrm{pH} 3.5$, whereas e maximum precipitation range for the trogen extends from $\mathrm{pH} 3.5$ to 5 . The ratio phosphorus to nitrogen increases on acidic le as far as this experiment concerns. Fig. 2 ows the amounts of the nitrogen and phoslorus precipitated at different calcium conntrations. It is apparent that calcium-pre- cipitated protein contains large quantity of phosphorus and the trend of solubilities of phosphorus corresponds to that of nitrogen. The ratio of phosphorus to nitrogen is higher than that of acid-precipitated protein, because the percentage of nitrogen precipitated by calcium salt is lower than that by acid.

The solubilities characteristics expressed as the amounts of total nitrogen, protein nitrogen, phosphorus and calcium in whole water extract, acid-precipitated protein and calciumprecipitated protein, as a function of $\mathrm{pH}$, are shown in Fig. 3-A, B and C. Fontaine et al. investigated protein-phytic acid relationship in peanut, cotton seed and soybean. ${ }^{21}$ That relationship in rice was reported by one of the authors. ${ }^{121}$ The solubility curve of whole water extract shown in Fig. 3-A is quite similar to that shown by Fontaine et al. on soybean and there is very little decrease in the solubility of phosphorus above $\mathrm{pH} 7$ in contrast to those in peanut, cotton seeds and rice as they also pointed out. In the solubility curve of acid-precipitated protein solution shown in Fig. 3-B, the minimum solubility range for nitrogen is narrower than
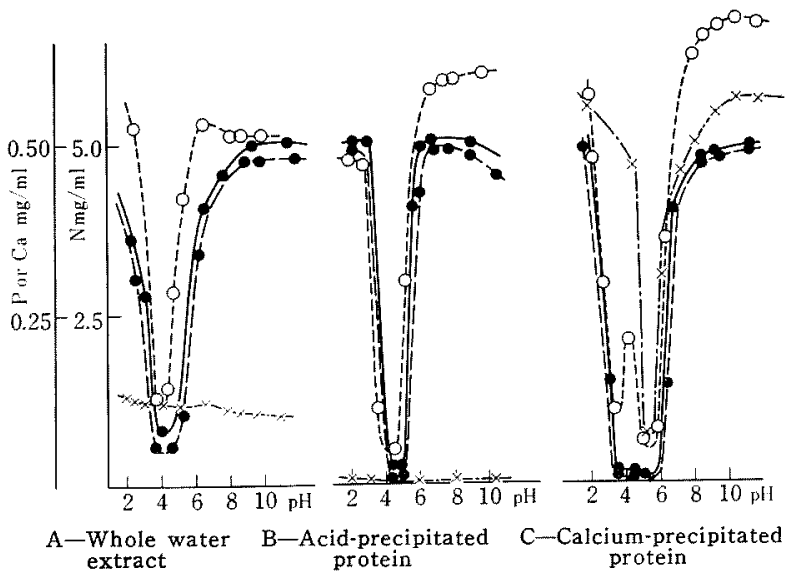

FIG. 3. Solubility Characteristics of Soybean Proteins at Different pH Values.

- total $\mathrm{N}$
- - protein $\mathrm{N}$ $\bigcirc-\bigcirc$ phosphorus $x-\times$ calcium

12) K. Saio and S. Kubo, J, Agr. Chem. Soc. Japan, 19, 217 (1965). 
that of whole water extract, extending between $\mathrm{pH} 4.1$ to 5.1 with sharp increase at both sides. In Fig. 3-C showing the solubility curve of calcium-precipitated protein, the minimum solubility range of nitrogen lies broadly from $\mathrm{pH} 3$ to 6 . A very sharp solubility of calcium at $\mathrm{pH} 5.7$ and two of phosphorus at $\mathrm{pH} 3.8$ and 5.7 are observed. It is interesting to note that phosphorus shows minimum point both at $\mathrm{pH} 3.8$ not coinciding with that of calcium and at $\mathrm{pH} 5.7$ coinciding with that of calcium, and that phosphorus and calcium still keep solubilities above $\mathrm{pH} \mathrm{8,} \mathrm{where} \mathrm{both} \mathrm{should}$ be expected to react each other and to form the precipitate of Ca-phytate (Fig. 5-B). In order to discuss possible combination among protein, calcium and phosphorus at alkaline range, calcium-precipitated protein solution was gel-filtered on Sephadex G-75. As the control, the gel-filtration of both reagent

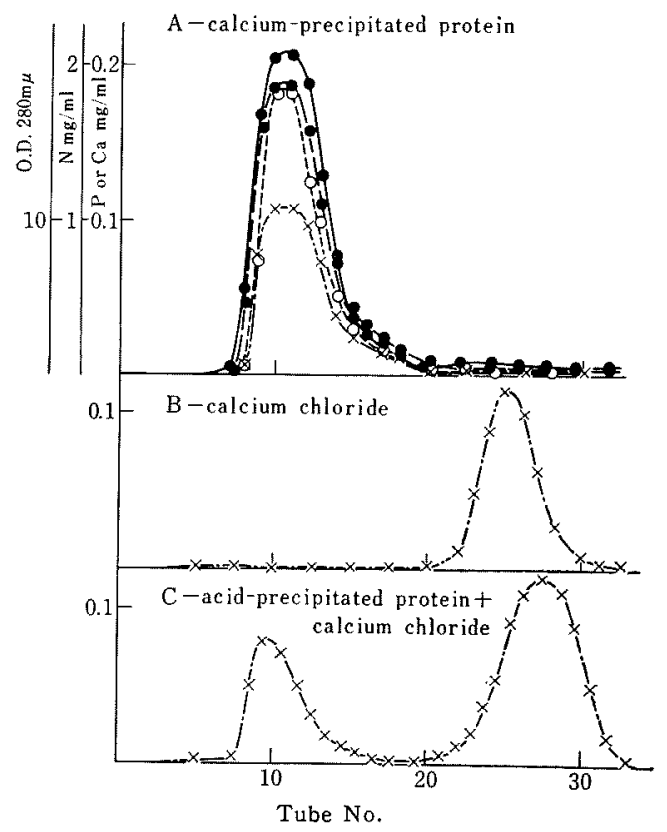

FIG. 4. Chromatogram on Sephadex G-75 Column for Separation of Bound Calcium.

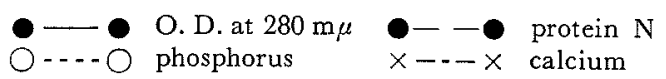

calcium chloride solution and the solution mix ture of acid-precipitated protein and calciur chloride was also carried out. In Fig. 4-A, $\mathrm{F}$ and $\mathrm{C}$, great majority of calcium in calcium. precipitated protein was eluted in the same tubes with protein, where the peaks of ab. sorbance values at $280 \mathrm{~m} \mu$ and phosphorus are identically indicated, whereas calcium in reagent calcium chloride was eluted later. In the case of acid-precipitated protein solution to which calcium chloride is added, calcium seems to be eluted in two groups, one is eluted with protein and the other is eluted in later stage, which might perhaps be calcium added excessively for protein. The data herein could lead the suggestion that there is something relate closely among protein, calcium and phosphorus (phytic acid) in alkaline solution as well as in precipitate.

But during the course of conducting the experiments, white flocculent precipitate was sometimes observed within several days, when calcium-precipitated protein solution was kept

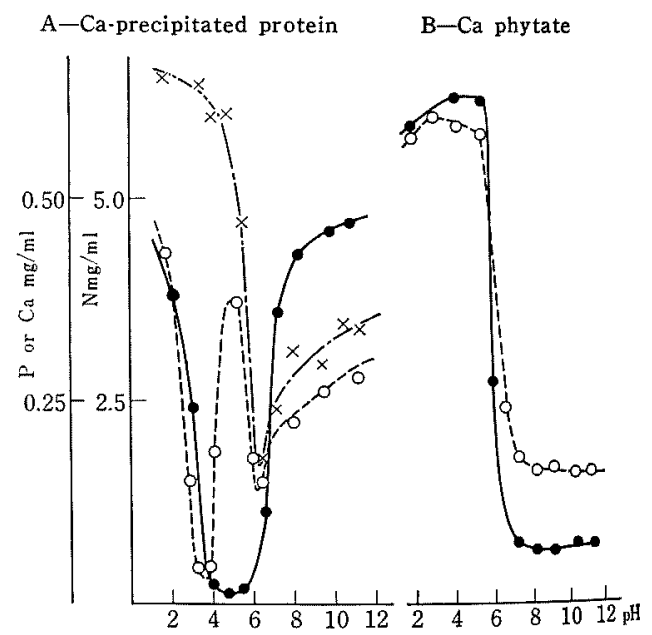

FIG. 5. Solubility Characteristics of Calcium-Precipitated Protein and Calcium Phytate.

Values in calcium-precipitated protein were analyzed after ultracentrifugation.

$\longrightarrow$ total $N$ calcium $O \cdots O$ phosphorus 
alkaline $\mathrm{pH}$, and also similar precipitate as observed within several hours, when the lcium-precipitated protein prepared with cessively added phytic acid was dissolved dilute alkaline solution. Although Fig. 5-A lows the solubility curve of calcium-precipited protein, it is different from Fig. 3-C at te point that the values in Fig. 5-A were demined after ultracentrifugation at $80,000 \times \mathrm{g}$ istead of low-speed centrifugation at $1,000 \times \mathrm{g}$. t alkaline $\mathrm{pH}$ above 8 , the solubilities of Ilcium and phosphorus decrease after ultraentrifugation, whereas that of protein does ot change. On the other hand, Fig. 5-B lows the solubilities of calcium and phoshorus in the mixture of reagents calcium bloride and sodium phytate. Calcium and hytic acid ions immediately react each other nd resulted in the precipitate with limited Jubility above $\mathrm{pH} 7$, which sediments easily ven at $1,000 \times \mathrm{g}$.

On the basis of available data, it can be ssumed that the combinations among protein, alcium and phytic acid are very labile in lkaline range and some part of complex is $\mathrm{n}$ the form of calcium phytate (phytic acid s not necessarily saturated with calcium).

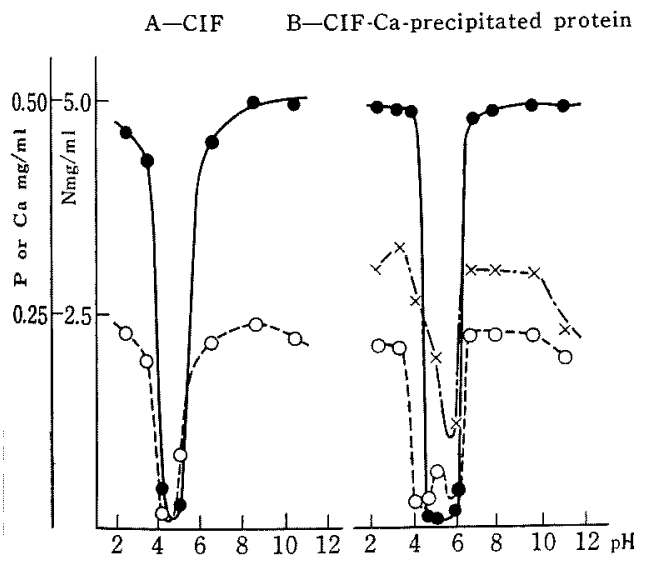

FIG. 6. Solubility Characteristics of CIF Protein and Calcium-Precipitated Protein from CIF.

$$
\text { - }
$$

Cold-insoluble fraction contained about $30 \%$ of phosphorus in that of original soybean meal extract and phytate-free protein about $10 \%$. Fig. 6-A indicates the solubility curves of cold-insoluble protein and Fig. 6-B shows those of calcium-precipitated protein from coldinsoluble fraction. The solubility characteristics of nitrogen, calcium and phosphorus in Fig. 6-B, comparing with the values in Fig. 3-C, are quite similar as a function of $\mathrm{pH}$ but calcium content per total nitrogen decreased.

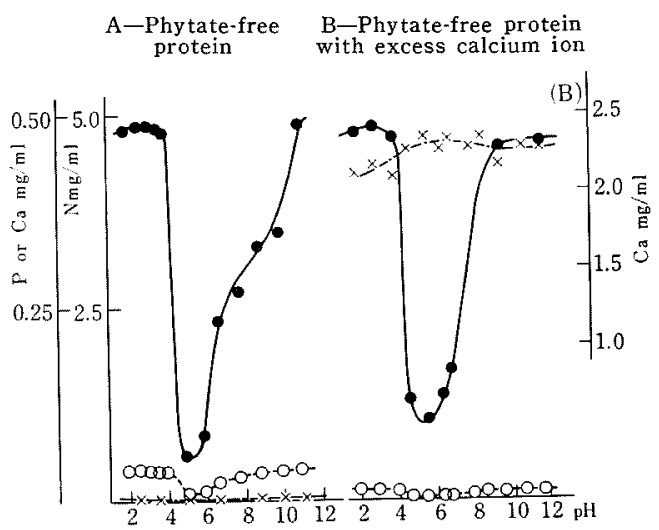

FIG. 7. Solubility Characteristics of Phytate-free Proteins.

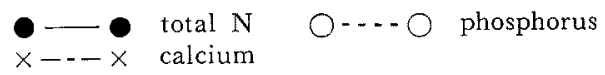

Fig. 7-A shows the solubility curve of phytate-free protein without addition of calcium ion, and Fig. 7-B shows that with addition of calcium ion. The minimum solubility range of total nitrogen in Fig. 7-A and $\mathrm{B}$ is shifted to $\mathrm{pH} 4.5 \sim 5.8$ from $3.5 \sim 5$ observed in Fig. 3-A and $\mathrm{B}$, and the solubility at acidic side below $\mathrm{pH} 4$ remarkably increases, whereas that at alkaline side increases gradually. As precipitate of phytate-free protein at $\mathrm{pH} 5.7$ contains little calcium, there is a small difference between Fig. 7-A and Fig. 7-B in the solubility of total nitrogen, leaving calcium in supernatant in Fig. 7-B.

These evidences suggest that calcium content 
in protein precipitates is effected by phosphorus content and that solubility characteristics are influenced by phosphorus content. However, the reasonable conclusion will be sent to the further work in progress, because there leave some doubts in the points that denaturation might occur on phytate-free protein during the treatment by ion-exchange resin and that cold-insoluble protein is different from initial soybean protein on the protein components, which consist of $89 \sim 90 \%$ of 11S.

Fig. 8-A and $B$ indicate the solubility characteristics of whole water extract after heating. Fig. 8-A shows those heated after $\mathrm{pH}$ adjustment and Fig. 8-B those heated before $\mathrm{pH}$ adjustment. But there seems little difference between Fig. 8-A and Fig. 8-B in insolubility characteristics of total nitrogen, calcium and phosphorus. Fig. 9-A and B show the solubility curves of acid-precipitated protein and calcium-precipitated protein after heating, respectively. In Figs. illustrating

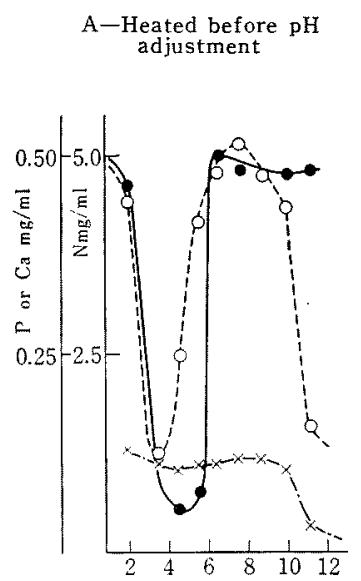

$$
\text { B-Heated after } \mathrm{pH}
$$
0

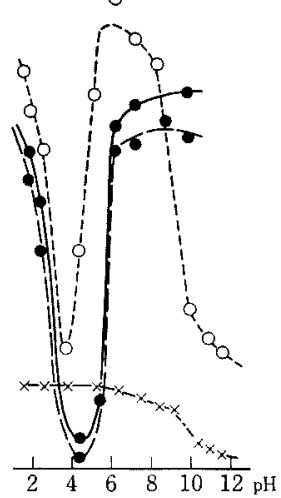

Fig. 8. Solubility Characteristics of Whole Water Extracts after Heating.

$\mathrm{A}$; heated before $\mathrm{pH}$ adjustment, $\mathrm{B}$; heated after $\mathrm{pH}$ adjustment.

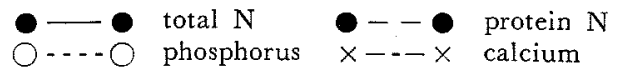

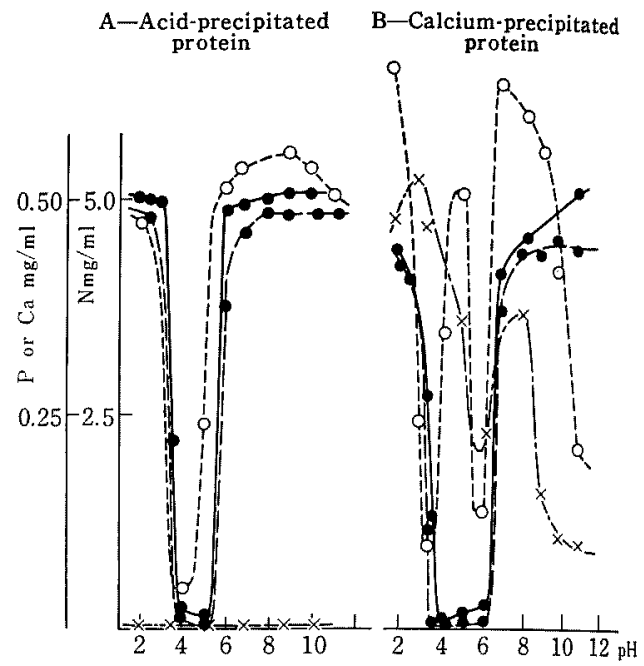

FIG. 9. Solubility Characteristics of Acid-Precipitated Protein and Calcium-Precipitated Protein after Heating.

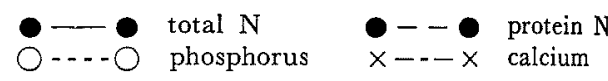

solubility characteristics after heating, the marked change by heating is observed above $\mathrm{pH} 7$ in the presence of calcium (Figs. 8 and Fig. 9-B). Solubilities of calcium and phosphorus decrease sharply, because heat treatment perhaps makes calcium and phosphorus more labile. But the minimum solubility range of phosphorus and calcium at $\mathrm{pH}$ 5.7 6.0 suggests the existence of combinations among protein, calcium and phytic acid at this range even after heating.

Acknowledgements. The authors are indebted to Mr. K. Kanna, Tokai Regional Fisheries Research Laboratory, for the facilities that are available in his laboratory. They thank Mr. A. Wakabayashi, Niigata Food Research Institute for his helpful assistance and also thank Mr. C. Tsutsumi, Food Analysis Division of Food Research Institute, for his advices.

The research was supported in part by a grant from U.S. Department of Agriculture provided to Japan Tofu Association. 